Article

Anna-Lena Scherer and Ute Schmiel*

\title{
Ethical and Legal Responsibility of Multinational Corporate Groups for a Fair Share of Taxes
}

https://doi.org/10.2478/ntaxj-2021-0002

Received Nov 23, 2020; revised Mar 27, 2021; accepted May 29, 2021

\begin{abstract}
This paper deals with the question whether there are reasons to deem multinational corporate groups ethically or legally responsible for paying their fair share of taxes. Ethical concepts argue that companies should generally be held responsible, but these findings contradict the mainstream market theory that understands companies as legal fictions and therefore not ethically but merely legally responsible. In contrast, we base our argumentation on the political-cultural market theory. We find that this theory provides reasons to ascribe an ethical responsibility for paying their fair share of taxes to multinational corporate groups. We argue, moreover, that this ethical responsibility also speaks for a legal responsibility. The prevailing tax law, particularly the arm's length principle, does generally not see groups as tax subjects. This currently missing legal responsibility gives reasons to rethink tax law. Therefore, we analyze whether the OECD Pillar One proposal may be an alternative to existing law.
\end{abstract}

Keywords: inequality, fair share of taxes, political-cultural market theory, group taxation, international taxation

\section{Introduction}

According to the OECD, countries lose revenue of between 100 and 240 billion USD annually because of tax avoid-

\footnotetext{
Anna-Lena Scherer: Research assistant at the Chair of Business Taxation, University of Duisburg-Essen, Germany. She works at the research project "Companies' fair share of tax-reasonable and realizable?”, which is funded by WTS Group AG Steuerberatungsgesellschaft.

${ }^{\star}$ Corresponding Author: Ute Schmiel: Professor of Business Taxation, University of Duisburg-Essen, Germany. E-mail: ute.schmiel@uni-due.de
}

Acknowledgement: We would like to thank the anonymous reviewer for their constructive suggestions and comments. ance, particularly that of multinational corporate groups (OECD 2015a). From the perspective of ethical concepts, such as a utilitarian approach, a framework according to John Rawls, or concepts of contractual rights (Payne and Raiborn 2018; Gribnau and Jallai 2017), tax avoidance is problematic. These concepts argue that companies should generally be held responsible for paying their fair share of taxes. The same is true for the perspective of corporate social responsibility (CSR) (Avi-Yonah 2014). Although these approaches leave out the question of how to define the fair share of taxes in detail, all of them interpret tax avoidance as ethically irresponsible behavior that results in inequality. The ethical responsibility of multinational corporate groups to pay their fair share of taxes is supported by the ethical perspective that companies should be seen as moral actors or as real entities. We can find the moral actor-view in Business Ethics (French 1979, 1984, 2017; Pettit 2007, 2017; Bratman 2017) and the real entity-view in Legal Philosophy (Phillips 1994; Robé 2011; Sikka and Stittle 2019) and in a certain social science perspective as well (Gindis 2009). Although these approaches focus on companies, we can also apply their reasoning to multinational corporate groups. What these approaches have in common is that they question the mainstream market theory's understanding of firms as legal fictions (Jensen and Meckling 1976; Fama 1980). From the legal fiction-perspective, there is no reason to deem companies or multinational corporate groups ethically responsible for paying their fair share of taxes. In particular, tax avoidance is not unethical and does not lead to inequality.

Yet, the current tax law is characterized by the "group is not a tax subject" idea. Accordingly, only the parent companies or the group members are legally responsible, not the multinational groups themselves. The arm's length principle, which is the predominant principle in international taxation, clearly reflects this idea since it treats the group members "as operating as separate entities rather than as inseparable parts of a single unified business" (OECD 2017a). One reason why tax law ignores the multinational corporate group may be that it refers less to the moral actor-view or the real entity-view but rather to the view that companies are merely legal fictions. This legal 
fiction-view stems from and is part of the positive mainstream market theory that dominates the market culture, as issues such as shareholder value primacy behavior of companies (Sikka 2015; Clarke, Jarvis, and Gholamshahi 2019) or the market-conforming tax policy of several countries (Christensen 2017) show. Certainly, mainstream market theory does not only deal with the understanding of firms (which it interprets as legal fictions) but, i.a., with the questions about what markets are and what markets can do. The above-mentioned critical approaches to the firms as legal fictions-view may not have refuted this until now since, though they contradict mainstream market theory, they do not argue from an alternative market theory perspective.

Thus, the present paper now focuses on whether multinational corporate groups should be held responsible for paying a fair share of taxes from an alternative market theory perspective. It aims to expose the ill-suited theoretical basis that underlies the "group is not a tax subject" idea. Furthermore, it aims to provide an alternative theoretical approach that could both replace mainstream market theory, particularly regarding the taxation of multinational corporate groups, with a completely different approach and support the ethical concepts that hold multinational corporate groups ethically responsible. For that, the present paper bases its argumentation on the politicalcultural market theory. In contrast to the above-mentioned social science approaches that interpret firms as real entities, the political-cultural market theory explicitly uses microfoundations, i.e., it explains macro-phenomena by individual behavior (Fligstein 2001; Fligstein and McAdam 2012). We argue that the political-cultural market theory provides reasons to ascribe an ethical responsibility to multinational corporate groups to pay a fair share of taxes.

When an ethical tax responsibility of multinational corporate groups is reasonable from the perspective of Business Ethics, Legal Philosophy, and from a market theory perspective, there are also reasons to introduce or at least to approximate a legal responsibility of multinational corporate groups. Therefore, this paper follows the comparative institutional approach (Albert 1985) and critically analyzes the current taxation of multinational corporate groups, which follows the idea that the "group is not a tax subject", in comparison with taxation alternatives. In particular, it asks whether the Inclusive Framework's Pillar One Blueprint, presented by the OECD (OECD 2020a), which discusses a new taxing right and a new nexus, takes the ethical responsibility of multinational corporate groups into account. Furthermore, we examine whether this proposal is suitable to reduce tax avoidance and whether it is realizable.
The paper proceeds as follows. Section 2 deals with methodological thoughts about the relation between ethical responsibility and legal responsibility. Furthermore, it points out the relevance of market theory in answering the question whether we have reasons to deem multinational corporate groups ethically responsible. Section 3 first shows that economic mainstream theory does not support the fair share of taxes responsibility but is itself non adequate. Section 3 then refers to the politicalcultural market theory and argues that it supports the ethical responsibility for a fair share of taxes of multinational corporate groups. Section 4 discusses the implications of an ethical responsibility to pay a fair share of taxes for a legal responsibility and critically analyzes the current OECD Inclusive Framework's Pillar One Blueprint (OECD 2020a). Section 5 summarizes the results.

\section{Some Methodological Thoughts about the Relation between Ethical Responsibility, Legal Responsibility, and Market Theory}

\subsection{The Relation between Ethical and Legal Responsibility}

When tax systems do not oblige multinational corporate groups to pay their fair share of taxes although the groups are responsible for doing so from an ethical perspective, tax systems lead to and even intensify inequality. To answer the question whether there are reasons to deem multinational corporate groups responsible, the present paper differentiates between ethical responsibility and legal responsibility to pay a fair share of taxes. Ethical responsibility refers to ethical concepts such as a utilitarian approach, a framework according to John Rawls, contractual rights concepts (Payne and Raiborn 2018; Gribnau and Jallai 2017), or the ethical and theoretical discussion that understands firms as moral actors (French 1979, 1984, 2017; Pettit 2007, 2017; Bratman 2017) or real entities (Phillips 1994; Robé 2011; Sikka and Stittle 2019). In general, ethical responsibility implies doing what is right and fair (Carroll 1979, 1991). Legal responsibility is the responsibility to obey the law, which is justified by various reasons, e.g., by the idea that membership in a community obligates one to follow the community's rules (Dagger and Lefkowitz 2014). Since legal responsibility originates in the 
fact that legislation results from democratic processes, legal responsibility is independent of whether it is founded on ethical concepts or on theories. If the law refers to the idea that the "group is not a tax subject", there is no legal responsibility although there may be reasons for an ethical responsibility.

However, ideally, there is a broad overlap between legal responsibility and ethical responsibility because the law should be based on what a society considers is right and fair. Thus, the taxation of multinational corporate groups should ideally be founded on ethical and theoretical concepts (Paine 1994). Yet, since there are different answers to the question what is right and fair, the legal and the ethical responsibility may differ-see, e.g., Gribnau and Jallai (2017), who differentiate between mere compliance with the letter of the law and an ethical responsibility that may go beyond this. There may be a legal responsibility without an ethical responsibility and vice versa. Depending on how much the ethical and legal responsibilities differ, the circles may (not at all, partially, or completely) overlap. Figure 1 illustrates this connection.

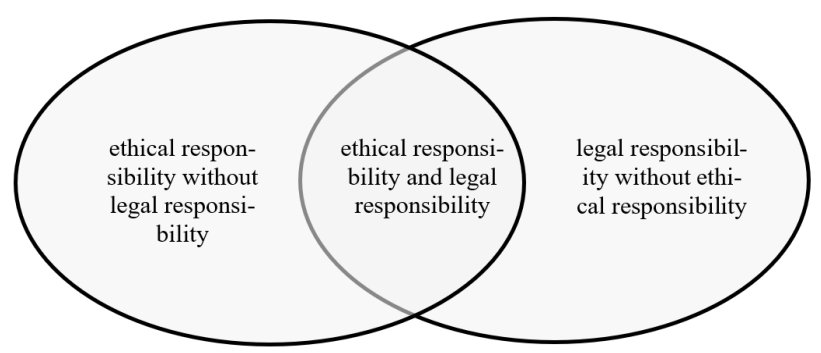

Figure 1: The Relation between Ethical and Legal Responsibilities.

As we mentioned in our introduction, we doubt that the "group is not a tax subject" idea of the current law is ethically founded. In consequence, we assume that there is an ethical responsibility of multinational corporate groups although a legal responsibility is missing. This gives reasons to rethink the current tax law.

\subsection{The Relation between Ethical Responsibility for a Fair Share of Taxes and Market Theory}

To substantiate ethical responsibility for a fair share of taxes, it is necessary to substantiate what is right and fair in the context of taxing multinational corporate groups. Since values are abstract, this requires ethical concepts, e.g., the contractual rights concept, according to which companies implicitly close a contract with society to pay their fair share of taxes (Payne and Raiborn 2018). This view is supported by concepts of moral actors (French 1979, 1984, 2017; Pettit 2007, 2017; Bratman 2014, 2017) and the interpretation that firms are real entities (Phillips 1994; Robé 2011; Sikka and Stittle 2019; Gindis 2009).

A main argument for the Business Ethics view of companies as moral actors is that, according to French, companies (which may mean separate companies as well as multinational corporate groups) have a corporate internal decision structure (French 1979, 1984). This structure serves as the basis of corporate intentionality and generally consists of an organizational flowchart, procedural rules, and policies. Corporate internal decision structures transform the acts and intentions of human beings into corporate decisions. Therefore, companies are moral actors and as such can be held responsible. Importantly, this does not mean that the individuals behind them cannot be held responsible as well and vice versa: if an individual behind a company is held responsible, the company can also be held responsible. Thus, if there are reasons to blame both, the company and the individual behind it, both can be held responsible. Additionally, French (2017) elaborates a concept of corporate moral responsibility over time. For this, he distinguishes between synchronic and diachronic responsibility. Synchronic responsibility refers to responsibility at the time of an event whereas diachronic responsibility concerns the responsibility for an act at a later time (and that may differ from the synchronic responsibility). Pettit $(2007,2017)$ also uses elements of French's corporate internal decision structure for his argumentation of companies as moral actors. According to Pettit, conversable agents are to be held responsible for their actions. These agents are characterized by three criteria: an agent maintains certain purposes, forms reliable representations of their environment, and acts to satisfy their purposes. Conversable means understanding the meaning of words, speaking as subjects with whom others can interact, and forming normative judgments based on internal structures. Companies as moral actors may have a voice of their own that is not just the aggregate of the individual voices. Pettit demonstrates that, due to inconsistencies that arise, group decisions are not the logical inferences of the corresponding decisions of the majority of individuals behind them (Pettit 2007, 2017; more generally on this discursive dilemma, see Pettit 2001). By finding compromises, the group members construct the voice and mind of the group itself, in this case of the company as moral actor, which is autonomous from the individuals. Pettit concludes that as companies (which may mean separate companies as well as multinational corporate groups) can be conversable agents, they can be held responsible for their 
actions. Similar to French, Pettit argues that companies and individuals behind them can be held responsible simultaneously. Also, according to Bratman $(2014,2017)$, we have reasons to argue that companies (which may mean separate companies as well as multinational corporate groups) are moral actors and, therefore, can be held responsible. He argues that there are group intentions that are not shared intentions and therefore lead to the responsibility of companies. Shared intentions are intentions that are shared among group members. Groups, or companies, may have implemented policies or procedures, especially decision-making procedures (e.g., decision-making based on majority votes). These procedures form a company's self-governance (broadly consistent with French's corporate internal decision structure). This can lead to procedure-based company intentions that can differ from shared intentions and therefore can lead to responsibility of companies.

Other approaches in favor of the responsibility of companies are the real entity approaches discussed in Legal Philosophy. According to these, companies are distinct corporate entities (Phillips 1994). Although there are many different real entity approaches, what they have in common is that they see corporations as "being with characteristics not present in their human members" (Phillips 1994). Therefore, companies can have moral obligations comparable to human beings and can generally be held responsible (Phillips 1994). In contrast to the firms as legal fictions-view, the Business Ethics and Legal Philosophy approaches presented above all argue in favor of the idea of holding companies responsible.

Yet, these critical approaches to the firms as legal fictions-view have not refuted it until now. We believe that this results from the fact that critical approaches do contradict economic mainstream theory with respect to the understanding of firms but do not do so from an alternative market theory perspective. For that reason, we refer to the political-cultural market theory as an alternative market theory. Since that market theory uses a microfoundation, it deals less with the question of what firms are, but rather with the question of how firms act. The ability to act in a social science sense, which may differ from the ability to act in a legal sense, is a strong argument for actor responsibility (Pettit 2017; French 2017). In consequence, if we come to the result that multinational corporate groups are able to act from a social science perspective, this is also a strong argument for holding them (and not only the shareholders) responsible for paying their fair share of taxes and for blaming them (and not only the shareholders) when they do not pay their fair share of taxes.
Explaining the behavior of multinational corporate groups from a social science perspective is rather complex when we choose a microfoundation. Following this methodological decision, we explain macrophenomena by analyzing individual behavior because macro-phenomena result from the behavior of individual actors (Opp 2011). Firms or multinational corporate groups, thus, do not behave in a literal sense; only individuals do. In consequence, "firm behavior" or "multinational corporate group behavior" are the outcome of individual behavior. Thus, the question arises whether it is reasonable to even speak of "firm behavior" or "multinational corporate group behavior." Some argue that there are differences in kind between the individual behavior of people in markets and the behavior of people in organizations. The reasons are that rules and further social mechanisms in companies coordinate the choices and behavior of individuals. In consequence, companies should be seen as corporate actors (Vanberg 1992).

Since this argumentation remains vague, the present paper argues that whether we have reasons to attribute an individual behavior to companies and especially to multinational corporate groups, depends on the underlying market theory. If, accordingly the "firm behavior" or "multinational corporate group behavior" is identical to the shareholders' behavior, we do not have reasons to attribute an individual behavior to the firm or the group. In contrast, if the market theory argues that the "firm behavior" or "multinational corporate group behavior" usually differs from the behavior of the shareholders, there are reasons to speak of an individual behavior of the firm or multinational corporate group (Schmiel 2019, 2020). Yet, in the case of multinational corporate groups, we must be more precise. Although there are different group definitions, one group characteristic is that groups usually consist of at minimum one subsidiary controlled by a parent company (Endres and Spengel 2015). A typical form of control is that the parent company directly or indirectly holds the majority of voting rights of the subsidiaries. Figure 2 describes a simple group structure.

In the case of groups, it is thus not sufficient to ask whether the behavior of the group represents the behavior of the shareholders of the parent company. Rather, the question is whether the behavior of the group also represents the behavior of those shareholders of the subsidiary who are individuals. In the case of the simple group structure in Figure 2, this implies looking at the shareholders behind both the subsidiary and the parent company.

Thus, we do not have reasons to ascribe individual behavior to the group from a market theory perspective when the multinational corporate group behavior repre- 


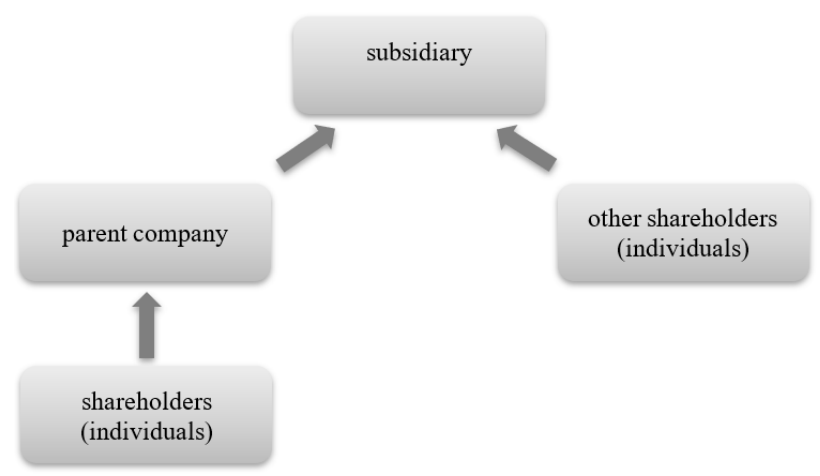

Figure 2: Simple Group Structure.

sents the behavior of the individual shareholders behind the subsidiaries and the parent company. Yet, we do have reasons to speak of an individual multinational corporate group behavior from a market theory perspective when the multinational corporate group behavior generally differs from the behavior of the individual shareholders behind the subsidiaries and the parent company. Figure 3 summarizes this.

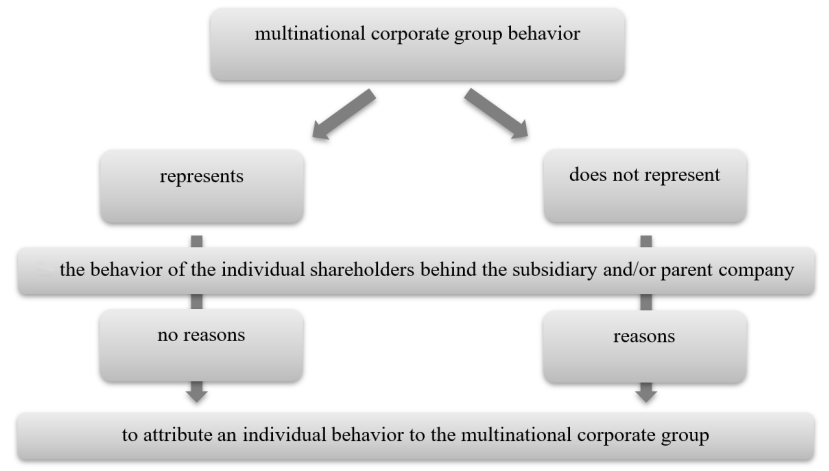

Figure 3: The Relation between Multinational Corporate Group Behavior and Behavior of Individual Shareholders.

To analyze the connection between the behavior of the individual shareholders and the behavior of the multinational corporate group, we apply Coleman's micromacro explanation (Coleman 1994; Opp 1992, 2011). On the macro-level, we can observe a correlation between taxation and the behavior of multinational corporate groups. Taxation is a variable of the macro-level and is linked to the micro-level. Since taxation influences relevant issues on the micro-level, it also influences individual behavior. Individual behavior leads to group behavior. Figure 4 summarizes these results.

Obviously, the relevant question is how taxes influence issues that influence individuals. This requires

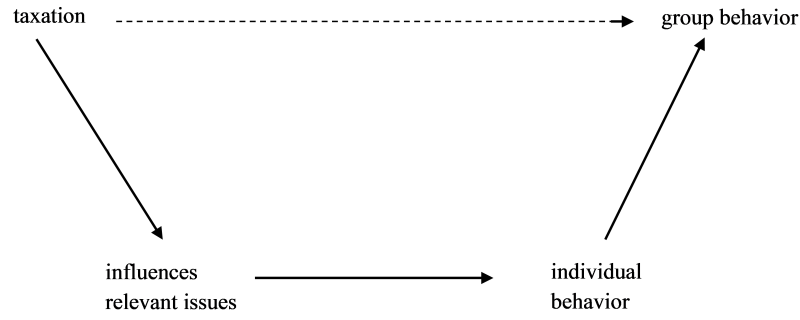

Figure 4: Group Behavior and the Micro-Macro Explanation.

knowledge of how individuals behave and how individual behavior is aggregated to the behavior on the macro-level. Therefore, answering the question whether there are reasons to deem multinational corporate groups ethically responsible needs a market theory to explain how individuals behave in markets and in firms.

\section{Ethical Responsibility of Multinational Corporate Groups for a Fair Share of Taxes from a Market Theory Perspective}

\subsection{Fair Share of Taxes from a Mainstream Market Theory Perspective}

The mainstream market theory argues that individuals maximize or, because of their bounded rationality, at least try to maximize their utility, which is often interpreted as financial utility in terms of their net present value (MasColell, Whinston, and Green 1995; Furubotn and Richter 2005). This also holds true for shareholders which expect to maximize their shareholder value (Furubotn and Richter 2005). Certainly, shareholders of large corporations or groups usually do not decide for or manage the corporation or the group. The shareholders (principals) authorize an executive board (agents) to manage the company, and mainstream market theory argues that managers behave in the interests of the shareholders. The market mechanism guarantees this correspondence between the shareholders' interests and the managers' behavior. This reasoning varies depending on the assumed grade of market perfection. Thus, the reasoning from a theory that assumes perfectly competitive markets differs from the reasoning of new institutional economics. In perfectly competitive markets, all actors are perfectly rational. Thus, managers do not have the possibility to behave opportunistically (Mas-Colell, Whinston, and Green 1995). 
Rather, managers must behave in the interest of shareholders. If they do not, they will have to suffer negative consequences. Managers who do not maximize the shareholder value risk their jobs. The reason is that in perfectly competitive markets, a shareholder value that is lower than the "real shareholder value" provides incentives to buy these shares and to replace the managers (Furubotn and Richter 2005). Furthermore, in perfectly competitive markets, there is no problem finding ways to maximize shareholder value. There are, e.g., no misinterpretations or misunderstandings by employees or other actors who have to implement the managerial decisions (Cyert and March 2003). Additionally, because of perfect rationality, there are no agency problems when employees or other actors implement the decisions (Furubotn and Richter 2005).

According to new institutional economics, the common goal of markets is to reach a higher level of individual utility (Furubotn and Richter 2005). Not only perfectly competitive markets but also markets under bounded rationality force managers to behave in the shareholders' interests. The reason is that the new institutional economics assumes actors have alternative options. Because of this, shareholders are symmetrically powerful. Since actors do not differ regarding their power, they do not have power to influence the behavior of other actors. Rather, each share reflects the same power and managers follow majority interests. Shareholders who do not agree with managers' behavior and who have a better alternative will opt out. Thus, the fact that shareholders hold their shares shows that managers behave in their interest or at least that remaining a shareholder of that firm is the best option. Although there is bounded rationality, misinterpretations do not occur. Agency problems matter but there are suitable mechanisms to reduce them (Furubotn and Richter 2005).

According to these hypotheses, mainstream market theory explains the behavior of groups regarding taxation as follows: taxation influences the individual utility of the shareholders. Since managers behave in the interest of the shareholders, they (try to) maximize the shareholder value after taxation (Timonen 2008). As there are no problems of misunderstanding or misinterpretation by employees and other actors who realize managers' decisions, the group behavior is the summation of managerial behavior, which, in turn, reflects the interests of shareholders. Figure 5 shows this influence of taxation on managers' and groups' behavior.

Since the group behavior represents the individual behavior of the shareholders, multinational groups are not able to behave from the perspective of these market theories. Moreover, since there is no reason to speak of individual group behavior and because of the relation between

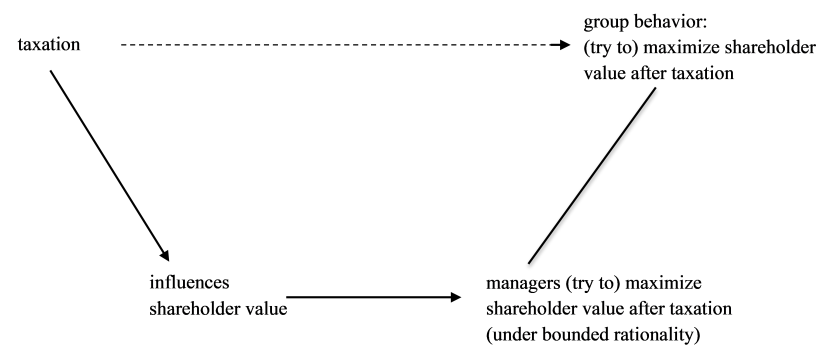

Figure 5: Group Behavior from a Mainstream Market Theory Perspective.

ethical responsibility and the ability to act from a social science perspective, there is no reason to deem multinational corporate groups responsible for paying their fair share of taxes. When multinational corporate groups do not pay their fair share of taxes, this does not lead to inequality. At most, there is an ethical responsibility on the part of the individual shareholders.

Yet, mainstream market theory has at least two flaws (Schmiel 2019). First, it is based on unrealistic assumptions that are not empirically confirmed, such as that of perfectly rational behavior. In fact, actors are faced with a large number of possible options and cannot assign objective probabilities to possible states of nature (Witt 2009). Second, neoclassical theory cannot endogenously explain many of the events we are confronted with in reality, such as innovations and learning of individuals, bankruptcy, the use of money, or the existence of institutions such as firms or multinational corporate groups (Shubik 2007). Thus, with respect to tax avoidance, neoclassical theory cannot adequately explain why some multinational corporate groups avoid taxes and others do not (Hanlon and Heitzman 2010). New institutional economics tries to mend this with so-called hybrid models, which combine contradictory assumptions, such as the idea that decision makers are perfectly informed about some matters but ignorant of others (Furubotn and Richter 2005). Since the logical value of the conjunction of two premises that contradict each other is "false", any statement can be inferred from falsity (Albert 1985; Schmiel and Sander 2021).

\subsection{Fair Share of Taxes from the Political-Cultural Market Theory Perspective}

According to the political-cultural market theory (Fligstein 2001; Fligstein and McAdam 2012; Schmiel and Sander 2021), actors try to secure their economic survival. They cannot maximize or minimize; perfectly rational behavior 
is not possible. Actors can only behave subjectively rationally or reasonably. To do so, they follow the culture of the field (Fligstein 2001).

The political-cultural market theory interprets markets as social and political arenas that enable structured exchange. That implies power and political behavior of market actors being relevant characteristics of markets. Market actors differ regarding their power. There are powerful actors who can influence the behavior of other actors and the rules of the field and there are less powerful actors who cannot do so. Powerful actors try to maintain, and less powerful actors try to develop a system of domination. To do so, they follow a certain market culture that helps actors justify their behavior as reasonable through its interpretative frameworks for actors and its definition of social relationships. The market culture reflects the interests of powerful actors. Managers behave according to the market culture of actors they perceive as powerful (Fligstein 2001). When the relevant market culture entails an interpretative framework that recommends reducing taxation by tax avoidance strategies, managers behave accordingly. In contrast, when the relevant market culture argues for paying a fair share of taxes, managers follow this recommendation. Whether managers' behavior is in the interest of certain shareholders depends on the shareholders' power. In contrast to mainstream market theory, we can expect that managers follow the culture of the field, and this may be in line with the shareholders' interests, but it is also possible that it differs from them. Thus, the managerial decisions on the micro-level reflect the interests of powerful actors but not automatically the majority of shareholder interests. Rather, there may be a small number of powerful shareholders, a single shareholder, or even an external actor who enforces their interests against a majority of shareholders with less power (Pfeffer and Salancik 2003; Bourdieu 2005; Fligstein 1996, 2001; Nienhüser 2008; Davis and Cobb 2010). This also holds true for the parent company. Although the parent company usually holds, directly or indirectly, the majority of voting rights, the political-cultural market theory argues that this does not imply that it has the power to realize its interests. It is certainly possible, but there is no mechanism that guarantees the correspondence between individual shareholder behavior and multinational corporate group behavior.

Furthermore, employees or other actors interpret managerial decisions, and we can expect that there are different interpretations. It is not clear how to realize decisions and how to choose the means to realizing them (Cyert and March 2003). Thus, the behavior that we ascribe to corporate actors on a macro-level is the result of managerial behavior on the micro-level (Coleman 1994; Opp 1992,
2011). In contrast to the economic mainstream approach, the behavior on the macro-level is usually not the analytical aggregation (summation) of the shareholders' behaviors. Instead, the relation between individuals is relevant also from the micro-level to the macro-level, and social structures and social conditions influence individual behavior (Gräbner and Kapeller 2018).

Finally, in contrast to mainstream economics, from the perspective of the political-cultural market theory (Fligstein 2001) there are no reasons to assume that actors have perfect alternative options. Beyond perfectly competitive markets, we cannot expect that shareholders will always have an adequate alternative unless all alternatives, e.g., giving shares away, will be accepted as adequate. Thus, remaining a shareholder does not prove that managers behave in the shareholders' interests.

While economists often assume that not only perfect markets but also markets in general are able to force managers to behave in the shareholders' interests (Furubotn and Richter 2005), the political-cultural market theory denies this. Thus, managerial decisions may be in the interest of the majority of the shareholders, but there is no mechanism that guarantees that. Figure 6 describes these connections.

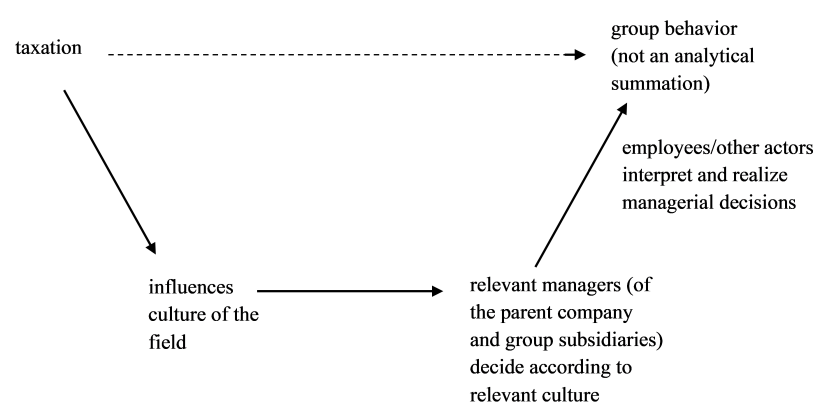

Figure 6: Group Behavior from the Political-Cultural Market Theory Perspective.

Since according to the political-cultural market theory, there is no mechanism that guarantees the correspondence of the group behavior on the macro-level with the shareholders' interests on the micro-level, we do have reason to doubt the legal fiction interpretation and to attribute individual behavior to multinational corporate groups. Because of this, there is also a good reason to attribute individual ethical responsibility to the group. Thus, it is reasonable to deem not only the shareholders but also the multinational corporate group ethically responsible for paying a fair share of taxes. It is, however, certainly difficult to define in detail the fair share of taxes of the multi- 
national corporate group. Although we have not dealt with the question what a fair share of taxes is and in particular, how much taxes multinational corporate groups should pay to fulfill their ethical obligations, we do have reasons to argue that tax avoidance is in conflict with ethical responsibility and leads to inequality.

Unlike the assumptions of the mainstream market theory, the assumptions of the political-cultural market theory do not contradict reality. Furthermore, empirical studies that deal with the determinants of firm behavior in the United States in the 1970s or the influences on mergers in the United States in the 1980s show that the politicalcultural market theory is able to explain different real-life issues (Fligstein 2001; Fligstein and Mc Adam 2012).

The present paper finds that, while the mainstream market theory contradicts these ethical concepts, such as a utilitarian approach, a framework according to John Rawls, or contractual rights concepts, and also the perspective that companies should be seen as moral actors or real entities, the political-cultural market theory provides an alternative view that is in line with them. From the perspective of the political-cultural market theory, there are reasons to deem multinational corporate groups ethically responsible for paying their fair share of taxes. Thus, this theoretical approach supports the ethical perspective (Payne and Raiborn 2018) that companies should generally be held responsible for paying their fair share of taxes.

\section{Implications of an Ethical Responsibility to Pay a Fair Share of Taxes for a Legal Responsibility}

\subsection{The Relation between Ethical Responsibility and Current Legal Responsibility}

The present paper provides a theoretical foundation from a market theory perspective for ethical responsibility and thus a necessary though insufficient first step to transforming society. A further important step in this direction is to introduce or at least to approximate a legal responsibility of multinational corporate groups. Section 2.1 shows the possible relation between ethical and legal responsibilities. According to Figure 1, there may be an overlap between them, or they may differ, so that we have an ethical responsibility without a legal responsibility (left cir- cle) or a legal responsibility without an ethical responsibility (right circle). Since we argue that a market theory perspective also gives reasons to deem multinational corporate groups ethically responsible, it makes sense to deal in detail with the missing legal responsibility of multinational corporate groups that the current law expresses in its idea that the "group is not a tax subject".

Usually, legal responsibility relates to the ability to be a legal actor, and that implies the ability to act in a legal sense, e.g., to close a contract (Stout 2017). Certainly, there are differences in legal systems regarding the extent of ability to act but that is not important for the following analysis. According to national corporate law, the separate companies, not the multinational corporate groups, are legal actors (Petrin and Choudhury 2018). Although corporate law does not treat multinational corporate groups as legal actors, it is at least aware of them. However, it does not assign legal obligations to the multinational corporate group but merely to the parent companies if at all. According to certain national corporate law systems, parent companies are, e.g., liable for the debts of their subsidiaries if certain conditions are fulfilled. In Germany and in other legal systems as well, the parent company is liable if there is an agreement between the parent company and their subsidiary about profit and loss absorption (Petrin and Choudhury 2018; Belenzon, Lee, and Patacconi 2018).

Furthermore, accounting law is also aware of multinational corporate groups and considers them. Many national accounting law systems differentiate between individual and consolidated financial statements (Ratliff 2003; IFRS Foundation 2020), but they deem the parent company and not the multinational corporate group responsible for providing the consolidated financial statement.

Finally, according to current tax law, multinational corporate groups are usually not subject to tax, but the separate group members are. National tax orders sometimes entail specific group taxation, particularly the consolidation of the group's income, but usually apply these rules only to national groups. National tax orders tax the separate entities, and international tax treaties also merely apply to the separate group members. The prevailing principle regarding the taxation of multinational corporate groups is the arm's length principle. It is laid down in national legislation as well as in international taxation, e.g., in the OECD Transfer Pricing Guidelines for Multinational Enterprises and Tax Administrations (OECD 2017a) and usually in article 9 of double tax treaties. According to the arm's length principle, prices between associated enterprises should be determined as prices between independent entities. The OECD Guidelines point out that the arm's length principle treats the group members "as operating 
as separate entities rather than as inseparable parts of a single unified business" (OECD 2017a) and therefore generally does not see groups as tax subjects. Similar to corporate law and accounting law, tax orders are also aware of multinational corporate groups (PWC 2020). According to the so-called country-by-country reporting rules that have been implemented worldwide in more than 80 countries (KPMG 2020), companies have to inform the respective responsible authorities about groups' profits, taxes, and economic activity (OECD 2015b). Nevertheless, as with corporate law and accounting law, this obligation does not apply to the group but usually to the parent company. Thus, to summarize, multinational groups are not legally responsible according to corporate law, accounting law, or current tax law. If anything, the parent company is responsible in this way. In consequence, there is an ethical responsibility but not a legal responsibility for multinational corporate groups. Describing the relation of (tax) legal responsibility and ethical responsibility in the light of Figure 1 means that we are in the left circle.

\subsection{Legal Responsibility according to the "OECD Inclusive Framework Report on Pillar One Blueprint"}

Since legislation should be founded on ethical or theoretical concepts, the ethical responsibility questions the prevailing taxation of multinational corporate groups. In the light of Albert's comparative institutional approach (Albert 1985), we should analyze taxation alternatives in comparison to the prevalent taxation. In consequence, we examine whether alternative forms of taxation take the ethical responsibility more into account than the prevalent taxation, whether they are, in fact, able to reduce tax avoidance, and whether they are realizable.

As mentioned in section 4.1, jurisdictions usually reject the idea that groups are actors from a legal perspective. Parent companies or the group members alone, not the multinational groups themselves, are legally responsible according to corporate law, accounting law, or tax law. Thus, the prevailing tax law is characterized by the idea that the "group is not a tax subject".

From the perspective of multinational corporate groups' ethical responsibility, this idea of the predominant arm's length principle that treats group members like independent separate entities is not reasonable. Furthermore, the application of the arm's length principle is complex (Couzin 2013). Additionally, it has facilitated tax avoidance (Heckemeyer and Overesch 2017; Liu, Schmidt-Eisenlohr, and Guo 2020). This is particularly the case in intercom- pany transactions without easily identifiable comparable transactions between independent companies. It is no wonder that the arm's length principle reaches its limits, particularly when it has to deal with intangible goods. The only advantage of the arm's length idea is that it is easy to manage between the relevant countries and that it is wellestablished and therefore obviously realizable.

If this predominant idea that the "group is not a tax subject" is one extreme, the opposite extreme would be to treat the group as an ethical and legal actor and consequently, as a tax subject. Treating the group as tax subject first implies full profit consolidation; second, a loss offset; and third, intercompany transaction elimination. From the perspective of the political-cultural market theory, treating groups as tax subjects is in line with ethical responsibility and, therefore, reasonable. Yet, it is by no means self-evident that treating groups as tax subjects reduces the extent of tax avoidance. Finally, treating groups as taxpayers requires considerable coordination and commitment of the concerned jurisdictions since it is necessary to agree on one obligatory solution and, especially, on one way of determining the allocable profit of multinational corporate groups since accounting rules may differ (Schreiber et al. 2020; Murphy and Sikka 2017; Murphy, Jansky, and Shah 2019). Therefore, the realizability of the "treating the group as tax subject" idea is at least doubtful (Schreiber et al. 2020; Bird 2018).

However, there are not only these two extremes of not seeing the group as tax subject or treating the group as tax subject, but also alternatives in between that should be considered. In the following, we will thus examine whether the currently much discussed (Eden and Treidler 2019a, 2019b; Samari 2019; Schreiber et al. 2020; OECD 2019a, 2019b1) proposal of the OECD Inclusive Framework, the Pillar One Blueprint (OECD 2020a) takes the ethical responsibility into account, whether it helps to reduce tax avoidance, and whether it is realizable. The initial ambitious timeline of the OECD Inclusive Framework has aimed to provide a final report on this approach until the end of 2020 (OECD 2019a, 2020b). Due to the COVID-19-pandemic and remaining issues, the OECD Inclusive Framework has recently renewed its commitment to reach a consensusbased solution, now by mid-2021 (OECD 2020a, 2020c) ${ }^{2}$.

1 In a first round of public consultation, the OECD received more than 300 public comments (OECD 2019b).

2 On 01.07.2021 the OECD Inclusive Framework published a statement outlining further details on the two-pillar approach (OECD 2021). 132 member jurisdictions have joined the statement by 09.07.2021. Compared to the Pillar One proposal examined here, changes particularly concern the scope: Pillar One shall no longer fo- 
In addition to the introduction of a new taxing right and a new nexus, the abandonment of the arm's length principle regarding specific profits is one of the groundbreaking innovations of this proposal. As presented in Figure 7, Pillar One is part of a two-pillar approach to "[a]ddress the Tax Challenges Arising from the Digitalisation of the Economy" (OECD 2019a, 2020a, 2020c, 2020d) next to Pillar Two. Pillar One focuses on a new taxing right and new nexus of taxation, certain profit allocation rules, allocation of taxing rights and tax certainty (OECD 2020a). In contrast, Pillar Two focuses on a global anti-base erosion mechanism and proposes a global minimum taxation (OECD 2020d). In the following, we focus on Pillar One, which is relevant for our subject.

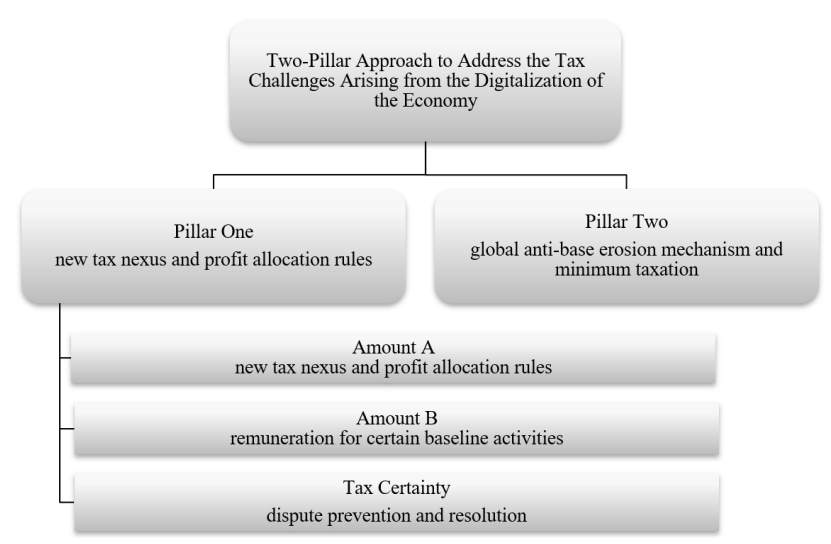

Figure 7: OECD’s Two-Pillar Approach.

As presented in Figure 7, Pillar One consists of three components, Amount A, Amount B, and the Tax Certainty element (OECD 2020a). Amount B shall provide a fixed return for "certain baseline marketing and distribution functions" (OECD 2020a, 11), consistent with the arm's length principle, while the last element shall increase tax certainty and cover dispute prevention and resolution for and beyond Amount A. We focus on Amount A, which is the groundbreaking innovation as it abandons the arm's length principle for certain activities, thereby at least partially recognizing the multinational corporate group, and which introduces a new tax nexus that is not linked to

cus on automated digital services and consumer-facing businesses. Now, multinational corporate groups that exceed certain turnover and profitability thresholds shall be in scope while extractives and regulated financial services are excluded. According to the statement, details on remaining issues and an implementation plan shall be finalised by October 2021. The G20 Finance Ministers and Central Bank Governors have endorsed the key components of the statement in their meeting in July 2021 (G20 Communique 2021). physical presence. According to Amount A, a deemed residual profit shall be allocated using a formulary apportionment method; this approach is to be applied at the multinational group level or the business line level. Due to digitalization and new business models, physical presence is no longer an adequate nexus for taxation in certain circumstances because an "active and sustained manner in the economic life of a market jurisdiction" (OECD 2020a, 19) is possible even without physical presence, as is the case with automated digital services, which can be provided to customers without using, e.g., the local infrastructure. Moreover, Amount A shall cover consumerfacing business, i.e., "those businesses that generate revenue from the sale of goods and services of a type commonly sold to consumers, including those selling indirectly through intermediaries and by way of franchising and licensing" (OECD 2020a, 21). Amount A shall thus cover automated digital services as well as consumerfacing businesses. Additionally, the new taxing right will apply only to groups that exceed various thresholds that still need to be developed (OECD 2020a, 2020b). The current proposal states that the Amount A tax base will be quantified using an adjusted profit before tax-figure based on consolidated group financial accounts and considering both profits and to some extent losses. Moreover, a specific reallocation percentage is to be determined to identify the share of residual profit that will be allocated to market jurisdictions (OECD 2020a). Once Amount A has been determined, the next step is the allocation to market jurisdictions using allocation keys. According to the proposal, the allocation "is based on in-scope revenue derived from each eligible market jurisdiction" (OECD 2020a, 128), so the proposal is still rather vague, and specification is needed regarding the allocation key as well as the profit to be allocated.

Although the proposal of the OECD Inclusive Framework does not fully reject the arm's length principle, it at least partially recognizes the group for tax purposes and therefore takes the ethical responsibility more into account than the arm's length principle, which generally refers to group members as independent separate entities. Hence, we have a partial overlap of the ethical responsibility and the legal responsibility. Nevertheless, since ethical responsibility does not automatically imply the reduction of tax avoidance, we should also analyze the approach regarding this issue. Furthermore, it is necessary to ask whether the approach is realizable.

As indicated above, the partial recognition of the group for tax purposes requires considerable coordination and commitment of the concerned jurisdictions and could enable tax avoidance. The profit measure of Amount 
A will be determined using consolidated group financial accounts prepared under IFRS. Consolidated financial accounts prepared under national GAAP that produce equivalent or comparable outcomes and whose use does not lead to significant distortions can be applied as well (OECD 2020a). Nevertheless, the determination of allocable profit and whether this determination may lead to tax planning opportunities is still unclear (Förster, Greil, and Hilse 2020). Furthermore, reducing tax avoidance requires a clear distinction between baseline activities and non-baseline activities. Additionally, segmented accounts would be needed to include only in-scope revenues. While one major problem of the application of the arm's length principle is finding comparable transactions, especially regarding unique goods, formulary apportionment methods are undoubtedly highly dependent on the choice of tax base as well as on the choice of apportionment factors (Brauner 2020). While opponents argue that the possibilities for tax avoidance by shifting what is chosen as the allocation key will remain high, Brauner (2020) finds that the costs of shifting currently discussed allocation keys like assets, personnel, or sales are far higher than those of shifting intangibles to avoid taxes under current tax rules. Even so, it is important that apportionment factors are linked to economic factors that are important for the group and cannot be artificially constructed by the group. The relevant factors should be designed in a way so that groups would harm themselves with tax avoidance activities (AviYonah and Benshalom 2011). Additionally, we have to expect tax avoidance opportunities to be increased by the implementation of Pillar One (Förster, Greil, and Hilse 2020). The reason is that Pillar One introduces a new nexus and a new taxing right covering digital businesses but generally does not address all existing problems of the arm's length principle, especially with respect to intangible assets. Instead, the formula-based apportionment regarding automated digital services and consumer-facing businesses is used alongside the arm's length principle (De Wilde 2020; Förster, Greil, and Hilse 2020). As a result, the possibilities for tax avoidance are even more likely to increase since the options for tax avoidance regarding the arm's length principle remain and new possibilities are added (Förster, Greil, and Hilse 2020).

Another aspect to consider about tax law is whether it is realizable. Amount A requires determining a deemed residual profit of a multinational corporate group. In general, the suitability of accounting law, such as IFRS or similar national GAAP, for determining the tax base is debatable (Förster, Greil, and Hilse 2020). Additionally, the IFRS can be interpreted differently by countries, which may hinder the determination of the allocable profits (Murphy, Jan- sky and Shah 2019; Murphy and Sikka 2017) and, therefore, the realizability. The OECD has already presented preliminary estimates on the effects of introducing the current proposal (OECD 2020e): The introduction of Pillar One and Pillar Two may lead to an increase in global corporate income tax revenues of $1.9 \%$ to $3.2 \%$. Depending on the specific design that is still to be determined, this would approximately amount to USD 50-80 billion annually. Yet, according to the OECD's preliminary estimates on the effects of the implementation of Pillar One, some states may lose tax revenues (OECD 2020e). So they may try to prevent the introduction, which may impede the general implementation (Schreiber et al. 2020). Moreover, the implementation of Pillar One requires major changes in national as well as international legislation, as already identified by the OECD (2020a). While changes in national legislation only depend on the commitment of one state, a consistent implementation on an international level is far more complex (De Wilde 2020). As mentioned above, the arm's length principle is part of bilateral tax treaties. Introducing the new Amount A-concept may require changing these treaties-although, e.g., Avi-Yonah (2010) discusses the possibility of preventing this by reinterpreting the arm's length principle. The OECD therefore suggests a multilateral convention for a simultaneous change (OECD 2020a). The realizability is still doubtful, though, as all states need to agree on one identical solution, and the coexistence of various regulations may lead to serious conflicts (De Wilde 2020). Although the OECD Inclusive Framework brings together more than 135 countries and jurisdictions and tries to reach a consensus-based solution on Pillar One, the proposals are not legally binding for members or nonmembers. The proposals are merely morally binding (OECD 2017b). Finally, according to the political-cultural market theory, actors try to secure their economic survival, and powerful actors can influence the behavior of other less powerful actors (Fligstein 2001; Fligstein and McAdam 2012). Since tax avoidance in market jurisdictions may be reduced by the new nexus, it is probable that more powerful actors who profit from the current tax system and may lose some of their advantages by the introduction of Pillar One will try to prevent this change (Schreiber et al. 2020; in general, Büttner and Thielemann 2017). In sum, although the OECD two-pillar approach recognizes the group at least in part more than the prevailing tax system, it is doubtful whether it is realizable.

Thus, the OECD approach represents an improvement in some parts but it also raises many questions and presents many challenges. First, although it at least partially recognizes multinational corporate groups, it does not seem to be suitable for achieving the goal of reduc- 
ing tax avoidance. Second, the political feasibility and enforceability of the proposal within the framework of a consensus-based solution is doubtful, as the consequences of its introduction are not predictable and the introduction may contradict the interests of powerful actors. It is therefore necessary to consider and analyze further alternatives between the two extremes, for example, group consolidation, which is nationally implemented in Austria and Denmark (PWC 2020), for example, or other proposals, such as a destination-based-corporate tax (Avi-Yonah 2016). Figure 8 provides an overview of the types of group taxation discussed above, showing both extremes and, as one alternative in between, the OECD Pillar One Blueprint.

\begin{tabular}{|c|c|c|c|c|}
\hline & & $\begin{array}{l}\text { Group as tax } \\
\text { subject }\end{array}$ & $\begin{array}{l}\text { OECD Pillar One } \\
\text { Blueprint }\end{array}$ & Prevailing tax rules \\
\hline \multirow{3}{*}{ 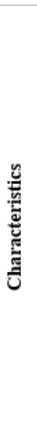 } & $\begin{array}{l}\text { Group as } \\
\text { tax subject }\end{array}$ & $\begin{array}{l}\text { Full: } \\
\text { group completely } \\
\text { accepted }\end{array}$ & $\begin{array}{l}\text { Partially: } \\
\text { group mostly not } \\
\text { seen as tax subject }\end{array}$ & $\begin{array}{l}\text { No: } \\
\text { group not seen as tax } \\
\text { subject }\end{array}$ \\
\hline & $\begin{array}{l}\text { Profit } \\
\text { consolidation } \\
\text { (also loss offset) }\end{array}$ & Yes & Partially & No \\
\hline & $\begin{array}{l}\text { Intercompany } \\
\text { transactions }\end{array}$ & Eliminated & $\begin{array}{l}\text { Transfer pricing: } \\
\text { arm's length } \\
\text { principle } \\
\text { Formulary } \\
\text { apportionment }\end{array}$ & $\begin{array}{l}\text { Transfer pricing: } \\
\text { arm's length } \\
\text { principle }\end{array}$ \\
\hline \multirow{3}{*}{ 胥 } & $\begin{array}{l}\text { Takes ethical } \\
\text { responsibility into } \\
\text { account }\end{array}$ & Yes & $\begin{array}{l}\text { More than transfer } \\
\text { pricing but less than } \\
\text { group as full tax sub- } \\
\text { ject }\end{array}$ & No \\
\hline & $\begin{array}{l}\text { Reducing } \\
\text { tax avoidance }\end{array}$ & $\begin{array}{l}\text { Probably more than } \\
\text { transfer pricing but } \\
\text { extent uncertain }\end{array}$ & $\begin{array}{l}\text { Probably more than } \\
\text { transfer pricing } \\
\text { (OECD 2020e) but } \\
\text { extent uncertain }\end{array}$ & $\begin{array}{l}\text { Enables } \\
\text { tax avoidance }\end{array}$ \\
\hline & Realizable & $\begin{array}{l}\text { Doubtful: } \\
\text { requires coordination } \\
\text { and commitment }\end{array}$ & $\begin{array}{l}\text { Doubtful: } \\
\text { Requires coordina- } \\
\text { tion and commitment } \\
\text { but less than the } \\
\text { group as tax subject }\end{array}$ & $\begin{array}{l}\text { Yes } \\
\text { (existing system) }\end{array}$ \\
\hline
\end{tabular}

Figure 8: Types of Group Taxation.

\section{Conclusion and Discussion}

The present paper asks whether there are reasons to deem multinational corporate groups ethically responsible for paying their fair share of taxes. Interpreting ethical responsibility requires referring to ethical concepts, such as a utilitarian approach, a framework according to John Rawls, or contractual rights concepts, and to market theories. Pay- ing a fair share of taxes seems to be indisputable from the perspective of ethical concepts (Payne and Raiborn 2018), which is also supported by the perspective that companies should be seen as moral actors (French 1979, 1984, 2017; Pettit 2007, 2017; Bratman 2014, 2017) or that they are real entities (Phillips 1994; Robé 2011; Sikka and Stittle 2019; Gindis 2009). However, paying a fair share of taxes is at odds with the mainstream market theory, which understands firms and also groups as legal fictions (Jensen and Meckling 1976; Fama 1980). From this perspective, there is no reason to deem groups responsible for paying their fair share of taxes; tax avoidance is not unethical and does not lead to inequality. Although the above-mentioned critical views of the mainstream market theory question the firms as legal fictions-view as they see firms as moral actors or real entities, the economic mainstream approach dominates the market culture and the rules, not only but also regarding the taxation of groups. Several issues such as the shareholder value primacy behavior of companies (Sikka 2015; Clarke, Jarvis, and Gholamshahi 2019) or the market-conforming tax policy of several countries (Christensen 2017) show this dominance.

In contrast to prevailing critical views that do not argue from an alternative market theory perspective, the present paper bases its argumentation on the politicalcultural market theory. The political-cultural market theory explicitly uses microfoundations and refers to theories about the behavior of individuals (Fligstein 2001; Fligstein and McAdam 2012). It combines this theoretical approach with the methodological view of Coleman's micro-macro explanation (Coleman 1994; Opp 1992, 2011). Thus, it does not assume that groups behave in a literal sense but understands group behavior as the result of individual behavior. The paper argues that the question whether we do have reasons to attribute an individual behavior to companies and especially to multinational corporate groups depends on the correspondence of group behavior to individual shareholder behavior. When the "multinational group behavior" represents the behavior of the individual shareholders who are behind the subsidiaries and the parent company, there are no reasons to ascribe an individual behavior to the group. Conversely, when there is a difference between both, there are reasons to speak of an individual multinational group behavior. Since group behavior is a strong argument for ascribing individual responsibility to the group, there are reasons to deem groups ethically responsible for paying their fair share of taxes. The paper finds that according to the political-cultural market theory, there is no mechanism that guarantees the correspondence of group behavior on the macro-level to the shareholders' interests on the micro-level. Thus, we do 
have reasons to question the legal fiction interpretation and to attribute an individual behavior to multinational corporate groups instead. In consequence, it is reasonable to attribute the group with its own ethical responsibility for paying the fair share of taxes. Thus, missing fair share of taxes of multinational corporate groups intensifies existing inequality. This also exacerbates inequality between individuals because it strengthens the prevailing shareholder primacy, which in itself intensifies inequality between individuals (Sikka 2015; Clarke, Jarvis, and Gholamshahi 2019).

Furthermore, the paper argues that this ethical responsibility also speaks for a legal responsibility. From the ethical point of view, there are more reasons to introduce a legal responsibility of groups than to maintain the prevailing not seeing the group as a tax subject. However, an introduction or at least an approximation of legal responsibility does not automatically reduce tax avoidance though it should be able to do so. Furthermore, it needs to be realizable.

While the prevailing tax law, in particular, the arm's length principle, generally does not see groups as tax subjects and therefore does not take ethical responsibility into account but facilitates tax avoidance, the full recognition of multinational corporate groups as tax subjects is in line with their ethical responsibility but uncertain as to tax avoidance and realizability. The OECD Inclusive Framework's Pillar One Blueprint as an alternative between the two extremes at least partially recognizes multinational corporate groups and thus takes the ethical responsibility more into account than the arm's length principle. However, it is also unclear whether its implementation will reduce tax avoidance and to what extent it is realizable.

In sum, treating a group (at least partially) as a taxpayer is more reasonable than the prevailing taxation. However, this requires further research on realizable formats which reduce tax avoidance by tying in issues that are relevant from the group's perspective and keep the required commitment of participating countries manageable.

Finally, the introduction of both ethical and legal responsibility requires replacing the prevailing mainstream market theory, according to which multinational corporate groups are legal fictions, by the political-cultural market theory. This, however, first requires an alternative culture and second, the power to change the field's rules. This power is relevant because, according to the politicalcultural market theory (Fligstein 2001), changing ethical or legal rules depends on the interests of dominant actors. Thus, theory-based arguments for ethical and legal responsibility are necessary steps but certainly not sufficient to change the culture of the field.

\section{References}

Albert, Hans. Treatise on Critical Reason. Princeton: Princeton University Press, 1985.

Avi-Yonah, Reuven, "Between Formulary Apportionment and the OECD Guidelines: A Proposal for Reconciliation," World Tax Journal 2, no. 1 (2010): 3-18.

Avi-Yonah, Reuven, "Corporate Taxation and Corporate Social Responsibility," Journal of Law and Business, no. 11 (2014): 1-29.

Avi-Yonah, Reuven, "Three Steps Forward, One Step Back? Reflections on 'Google Taxes' and the Destination-Based Corporate Tax," Nordic Tax Journal, no. 2 (2016): 69-76.

Avi-Yonah, Reuven, and Ilan Benshalom. "Formulary Apportionment: Myths and Prospects-Promoting Better International Policy and Utilizing the Misunderstood and Under-Theorized Formulary Alternative," World Tax Journal 3 no. 3 (2011): 371-98.

Belenzon, Sharon, Hongii Lee, and Andrea Patacconi, "Towards a Legal Theory of the Firm: The Effects of Enterprise Liability on Asset Partitioning, Decentralization and Corporate Group Growth," NBER Working Paper No. w24720, 2018.

Bird, Richard, “Are Global Taxes Feasible?” International Tax and Public Finance no. 5 (2018): 1372-1400.

Bourdieu, Pierre. "Principles of an Economic Anthropology." In The Handbook of Economic Sociology 2nd ed., edited by Neil J. Smelser and Richard Swedberg, (2005): 75-89. Princeton: Princeton University Press.

Bratman, Michael E. Shared Agency: A Planning Theory of Acting Together. Oxford: Oxford University Press, 2014.

Bratman, Michael E. 2017. "The Intentions of a Group." In The Moral Responsibility of Firms, edited by Eric W. Orts and N. Craig Smith, 36-52. Oxford: Oxford University Press.

Brauner, Yariv. 2020. "Between Arm's Length and Formulary Apportionment." In The Allocation of Multinational Business Income: Reassessing the Formulary Apportionment Option, edited by Rick Krever and François Vaillancourt, 209-38. Alphen aan den Rijn: Kluwer Law International B.V.

Büttner, Tim, and Matthias Thielemann. "Breaking Regime Stability? The Politicization of Expertise in the OECD/G20 Process on BEPS and the Potential Transformation of International Taxation." ACcounting, Economics, and Law: A Convivium 7, no. 1 (2017): 75782.

Carroll, Archie B., "A Three Dimensional Conceptual Model of Corporate Performance," The Academy of Management Review 4, no. 4 (1979): 497-505.

Carroll, Archie B., "The Pyramid of Corporate Social Responsibility: Toward the Moral Management of Organizational Shareholders," Business Horizons 34, no. 4 (1991): 39-48.

Christensen, Johan. The Power of Economists Within the State. Stanford: Stanford University Press, 2017.

Clarke, Thomas, Walter Jarvis, and Soheyla Gholamshahi. "The Impact of Corporate Governance on Compounding Inequality: Maximising Shareholder Value and Inflating." Critical Perspectives on Accounting, no. 63 (2019): 102049. 
Coleman, James S. 1994. "A Rational Choice Perspective on Economic Sociology." In The Handbook of Economic Sociology, edited by Neil J. Smelser and Richard Swedberg, 166-80. Princeton: Princeton University Press.

Couzin, Robert. "Policy Forum: The End of Transfer Pricing?" Canadian Tax Journal 61, no. 1 (2013): 159-78.

Cyert, Richard Michael, and James G. March. A Behavioral Theory of the Firm. 2nd ed., Reprint, Digital Print. Malden, Mass: Blackwell Business, 2003.

Dagger, Richard, and David Lefkowitz. 2014. "Political Obligation.” In Stanford Encyclopedia of Philosophy, edited by Edward N. Zalta. Stanford: Stanford Encyclopedia of Philosophy.

Davis, Gerald, and Adam J. Cobb. 2010. "Resource Dependence Theory: Past and Future." In Research in the Sociology of Organizations. Stanford's Organization Theory Renaissance, 1970-2000. Vol. 28. edited by Claudia Bird Schoonhoven and Frank Dobbin, 21-42. Bingley: Emerald Group Publishing Limited.

De Wilde, Maarten Floris. “On the OECD'S 'Unified Approach' as Frankenstein's Monster and a Dented Shape Sorter," Intertax 48, no. 1. (2020): 9-13.

Eden, Lorraine, and Oliver Treidler. 2019. "INSIGHT: Taxing the Digital Economy-Pillar One Is Not BEPS 2 (Part 1).” Bloomberg Tax (November 8, 2019): 1-5.

Eden, Lorraine, and Oliver Treidler. "INSIGHT: Taxing the Digital Economy-Pillar One Is Not BEPS 2 (Part 2)." Bloomberg Tax (November 12, 2019): 1-7.

Endres, Dieter, and Christoph Spengel. International Company Taxation and Tax Planning. Aalphen aan den Rijn: Kluwer Law International B.V., 2015.

Fama, Eugene F. "Agency Problems and the Theory of the Firm." Journal of Political Economy 88, no. 2 (1980): 288-307.

Fligstein, Neil. "Markets as Politics: A Political-Cultural Approach to Market Institutions." American Sociological Review 61, no. 4 (1996): 656-73.

Fligstein, Neil. The Architecture of Markets: An Economic Sociology of Twenty-First-Century Capitalist Societies. Princeton: Princeton University Press, 2001.

Fligstein, Neil, and Doug McAdam. A Theory of Fields. Oxford: University Press, 2012.

Förster, Hartmut, Stefan Greil, and Arnim Hilse. 2020. "Taxing the Digital Economy - The OECD Secretariat's New Transfer Pricing AB-C and Alternative Courses of Action." International Transfer Pricing Journal 27 (1): 3-18.

French, Peter A. 1979. “The Corporation as a Moral Person.” American Philosophical Quarterly 16 (3): 207-15.

French, Peter A. Collective and Corporate Responsibility. New York: Columbia University Press, 1984.

French, Peter A. "The Diachronic Moral Responsibility of Firms." In The Moral Responsibility of Firms, edited by Eric W. Orts and N. Craig Smith, 53-65. Oxford: Oxford University Press.

Furubotn, Eirik G., and Rudolf Richter. 2005. Institutions and Economic Theory: The Contribution of the New Institutional Economics. 2nd ed., Michigan: The University of Michigan Press.

G20 Communique. 2021. "Italian G20 Presidency Third Finance Ministers and Central Bank Governors meeting Communiqué 9-10 July 2021." https://www.g20.org/wp-content /uploads/2021/07/Communique-Third-G20-FMCBG-meeting-910-July-2021.pdf. Assessed July 19, 2021.
Gindis, David. "From Fictions and Aggregates to Real Entities in the Theory of the Firm." Journal of Institutional Economics 5, no. 1 (2009): 25-46.

Gräbner, Claudius, and Jakob Kapeller. 2018. "The Micro-Macro Link in Heterodox Economics." In The Routledge Handbook of Heterodox Economics, edited by Tae-Hee Jo, Lynne Chester, and Carlo D'Ippolti, 145-59. New York: Routledge.

Gribnau, Hans J.L.M., and Ave-Geidi Jallai. "Good Tax Governance: A Matter of Moral Responsibility and Transparency." Nordic Tax Journal, no. 1 (2017): 70-88.

Hanlon, Michelle, and Shane Heitzman. "A Review of Tax Research." Journal of Accounting and Economics 50, nos. 2-3 (2010): 127-78.

Heckemeyer, Jost H., and Michael Overesch. "Multinationals' Profit Response to Tax Differentials: Effect Size and Shifting Channels." Canadian Journal of Economics 50, no. 4 (2017): 965-94.

IFRS Foundation (International Financial Reporting Standards Foundation). 2020. "Who Uses IFRS Standards?" https://www.ifrs.org/use-around-the-world/use-of-ifrsstandards-by-jurisdiction/. Accessed November 15, 2020.

Jensen, Michael C., and William H. Meckling. "Theory of the Firm: Managerial Behavior, Agency Costs and Ownership Structure." Journal of Financial Economics 3, no. 4 (1976): 305-60.

KPMG. 2020. "BEPS Action 13: Country Implementation Summary." https://assets.kpmg/content/dam/kpmg/us/pdf/2020 /07/beps-action-13-jul30-2020.pdf. 2020. Accessed November 15, 2020.

Liu, Li, Tim Schmidt-Eisenlohr, and Dongxian Guo. "International Transfer Pricing and Tax Avoidance: Evidence from Linked TradeTax Statistics in the United Kingdom." The Review of Economics and Statistics 102, no. 4 (2020): 766-78.

Mas-Colell, Andreu, Michael D. Whinston, and Jerry R. Green. Microeconomic Theory. New York: Oxford University Press, 1995.

Murphy, Richard, Petr Jansky, and Atul Shah. "BEPS Policy Failurethe Case of EU Country-By-Country Reporting." Nordic Tax Journal, no. 1 (2019): 63-86.

Murphy, Richard, and Prem Sikka. 2017. "Unitary Taxation: the Tax Base and the Role of Accounting." In Taxing Multinational Enterprises as Unitary Firms, edited by Sol Picciotto, 75-89. Brighton: ICTD.

Nienhüser, Werner. 2008. "Resource Dependence Theory-How Well Does It Explain Behavior of Organizations?" Management RevueSocio-Economic Studies 19, nos. 1-2: 9-32.

OECD (Organisation for Economic Co-operation and Development). Measuring and Monitoring BEPS, Action 11-2015 Final Report, OECD/G20 Base Erosion and Profit Shifting Project. Paris: OECD Publishing, 2015a.

OECD (Organisation for Economic Co-operation and Development). Transfer Pricing Documentation and Country-by-Country Reporting, Action 13-2015 Final Report, OECD/G20 Base Erosion and Profit Shifting Project. Paris: OECD Publishing, 2015b.

OECD (Organisation for Economic Co-operation and Development). OECD Transfer Pricing Guidelines for Multinational Enterprises and Tax Administrations Paris: OECD Publishing, 2017a.

OECD (Organisation for Economic Co-operation and Development). Background Brief-Inclusive Framework on BEPS. Paris: OECD Publishing, 2017b.

OECD (Organisation for Economic Co-operation and Development). Programme of Work to Develop a Consensus Solution to the Tax Challenges Arising from the Digitalisation of the Economy, 
OECD/G20 Inclusive Framework on BEPS. Paris: OECD Publishing, 2019a.

OECD (Organization for Economic Cooperation and Development). Public Comments Received on the Secretariat Proposal for a "Unified Approach" under Pillar One. Paris: OECD Publishing, 2019b.

OECD (Organisation for Economic Co-operation and Development). Tax Challenges Arising from Digitalisation-Report on Pillar One Blueprint: Inclusive Framework on BEPS, OECD/G20 Base Erosion and Profit Shifting Project. Paris: OECD Publishing, 2020a.

OECD (Organisation for Economic Co-operation and Development). Statement by the OECD/G2O Inclusive Framework on BEPS on the Two-Pillar Approach to Address the Tax Challenges Arising from the Digitalisation of the Economy-January 2020, $O E C D / G 20$ Inclusive Framework on BEPS. Paris: OECD Publishing, 2020b.

OECD (Organisation for Economic Co-operation and Development). Cover Statement by the Inclusive Framework on the Reports on the Blueprints of Pillar One and Pillar Two. Paris: OECD Publishing, 2020c.

OECD (Organisation for Economic Co-operation and Development). "Tax Challenges Arising from Digitalisation-Report on Pillar Two Blueprint: Inclusive Framework on BEPS, OECD/G20 Base Erosion and Profit Shifting Project" Paris: OECD Publishing, 2020d.

OECD (Organisation for Economic Co-operation and Development). Tax Challenges Arising from Digitalisation-Economic Impact Assessment: Inclusive Framework on BEPS, OECD/G20 Base Erosion and Profit Shifting Project. Paris: OECD Publishing, 2020e.

OECD (Organisation for Economic Co-operation and Development). Statement on a Two-Pillar Solution to Address the Tax Challenges Arising From the Digitalisation of the Economy. Paris: OECD Publishing, 2021.

Opp, Karl-Dieter. "Micro-Macro Transitions in Rational Choice Explanations." Analyse \& Kritik 14, no 2 (1992): 143-51.

Opp, Karl-Dieter. "Modeling Micro-Macro-Relationships: Problems and Solutions." Journal of Mathematical Sociology 35, nos. 1-3 (2011): 209-34.

Paine, Lynn S. "Law, Ethics, and Managerial Judgement." Journal of Legal Studies Education 12, no. 2 (1994): 153-70.

Payne, Dinah, and Cecily Raiborn. "Aggressive Tax Avoidance: A Conundrum for Stakeholders, Governments, and Morality." Journal of Business Ethics 147, no. 3 (2018): 469-87.

Petrin, Martin, and Barnali Choudhury. "Group Company Liability." European Business Organization Law Review 19, no. 4 (2018): 77196.

Pettit, Philip. "Deliberative Democracy and the Discursive Dilemma." Philosophical Issues 11, no. 1 (2001): 268-99.

Pettit, Philip. “Responsibility Incorporated." Ethics January 117, no. 2 (2007): 171-201.

Pettit, Philip. 2017. “The Conversable, Responsible Corporation.” In The Moral Responsibility of Firms, edited by Eric W. Orts and N. Craig Smith, 15-35. Oxford: Oxford University Press.

Pfeffer, Jeffrey, and Gerald R. Salancik. The External Control of Organizations: A Resource Dependence Perspective. Stanford: Stanford University Press, 2003.
Phillips, Michael J. "Reappraising the Real Entity Theory of the Corporation.” Florida State University Law Review 21, 4 (1994): 10611123.

PWC. 2020. "Worldwide Tax Summaries Online." https:// taxsummaries.pwc.com/. Accessed November 15, 2020.

Ratliff, James. 2003. "Consolidated Financial Accounts and Business Combinations." In International Finance and Accounting Handbook, edited by Frederick Choi, 18.1-19. New York: Wiley.

Robé, Jean-Phillipe. "The Legal Structure of the Firm." Accounting, Economics, and Law: A Convivium 1, no. 1 (2011): 1-86.

Samari, Alessandro. "The OECD Secretariat Proposal for a 'Unified Approach' under Pillar One: Strengths and Weaknesses of the New and Revised Nexus and Profit Allocation Rules." International Transfer Pricing Journal 27, no. 2 (2019): 99-104.

Schmiel, Ute. "Corporate Social Responsibility: A Fake Already According to the Theory of the Firm?" Management Revue-SocioEconomic Studies 30, nos. 2/3 (2019): 154-72.

Schmiel, Ute. "Economic Analysis of Tax Law from a Sustainability Perspective." Florida Tax Review 23, no. 2 (2020): 597-624.

Schmiel, Ute and Hendrik Sander. "What are markets? Selected market theories under genuine uncertainty in comparison." Journal of Evolutionary Economics (2021).

Schreiber, Ulrich, Dirk Simons, Stefan Greil, and Martin Lagarden. "Why the Arm's Length Principle Should Be Maintained." International Transfer Pricing Journal 27, no. 6 (2020): 1-10.

Shubik, Martin. 2007. "Accounting and Its Relationship to General Equilibrium Theory." In The Firm as an Entity: Implications for Economics, Accounting and the Law, edited by by Yuri Biondi, Arnaldo Canziani, and Thierry Kirat, 73-81. Abingdon: Routledge.

Sikka, Prem. "The Hand of Accounting and Accountancy Firms in Deepening Income and Wealth Inequalities and the Economic Crisis: Some Evidence." Critical Perspectives on Accounting, no. 30 (2015): 46-62.

Sikka, Prem, and John Stittle. "Debunking the Myth of Shareholder Ownership of Companies: Some Implications for Corporate Governance and Financial Reporting." Critical Perspectives on Accounting, no. 63 (2019): 101992.

Stout, Lynn. 2017. "The Economic Nature of the Corporation." In The Oxford Handbook of Law and Economics: Volume 2: Private and Commercial Law, edited by Francesco Parisi, 337-57. Oxford: Oxford University Press.

Timonen, Pekka. 2008. "Corporate Social Responsibility and Strategic Tax Behavior-Comment on the Paper by Reuven S. Avi-Yonah." In Tax and Corporate Governance, edited by Wolfgang Schön, 199203. Berlin: Springer.

Vanberg, Viktor. "Organizations as Constitutional Systems." Constitutional Political Economy 3, no. 2 (1992): 223-53.

Witt, Ulrich. "Novelty and the Bounds of Unknowledge in Economics." Journal of Economic Methodology 16, no. 4 (2009): 361-75. 